\title{
Protection of Human Rights and Freedoms in the Administrative Proceedings of the European Union
}

\author{
Oleksandr Rastorhuiev¹, Petro Makushev², Alla Pukhtetska³, Andriy Hridochkin ${ }^{4}$, \\ Irina Smaznova ${ }^{5}$ \\ ${ }^{1}$ Department of Criminal Law and Process, National Aviation University, Ukraine. E-mail: \\ rastorhuiev8191@edu-knu.com \\ 2 Department of History and Theory of State and Law, University of Customs and Finance, Ukraine. E-mail: \\ makushev8191@neu.com.de \\ 3 Department of Administrative Law, Taras Shevchenko National University of Kyiv, Ukraine. E-mail: \\ pukhtetska8191@sci-univ.com \\ 4 Department of Entrepreneurship, Organization of Production and Theoretical and Applied Economics, \\ Ukrainian State University of Chemical Technology, Ukraine.E-mail: hridochkin8191@edu.cn.ua \\ 5 Department of Philosophy, National University "Odessa Law Academy", Ukraine. E-mail: \\ smaznova8191@acu-edu.cc
}

\begin{abstract}
Since there is a problem of forming a system of modern doctrinal knowledge on protection in administrative proceedings by individuals of their rights violated in public relations, the topic under research becomes relevant. The justice in national administrative cases requires qualitative improvement taking into account European experience. The purpose of the research is to form a uniform judicial enforcement in the field of public relations, establish the rule of law, and provide fair justice. The methodological basis of this study is a set of general scientific (dialectical, analysis, and synthesis), as well as special legal (historical, comparative law, consideration and interpretation of legal norms, formal-logical) methods of scientific knowledge. The practical significance of the obtained results is that the formulated theoretical provisions, proposals and recommendations can be used: in research to conduct further research on the problems of administrative proceedings in Ukraine, ways and means of effective protection of subjective rights of individuals; in law-making for further improvement in accordance with European principles of national legislation; in the law enforcement practice of judges of administrative courts of Ukraine for consideration and resolution of public law disputes, in the protection of their rights in administrative judicial specialization by citizens and legal entities.
\end{abstract}

Keywords: Administrative Justice; Case Law; Civil Rights; European Administrative Space; Human Rights

\section{Introduction}

In the process of association with the European Union (EU), the study of relevant experience in the functioning of EU law and judicial bodies can be of great importance for improving the national legal framework and direct judicial protection of the rights and legitimate interests of individuals in relations with public administration. The system of proper protection of human rights and freedoms is one of the important conditions of the European administrative space. The effectiveness of the national system for ensuring 
the protection of human rights and freedoms depends on the success of the process of implementation and convergence of European Union legislation, taking into account not only its content but also its form. The experience of many European countries proves that administrative courts are an accessible and effective tool for protecting human rights, freedoms and interests from violations by public authorities and local governments. It is known that the formation of administrative justice in Ukraine was based on the existing legal systems of developed European countries: Germany, France, Poland, as well as the best experience of judicial practice, forming the European system of human rights protection.

Further reform of administrative justice is impossible without taking into account the experience of the European Union. Judicial administrative control forms a full-fledged mechanism for protecting the state and society from illegal legal acts, decisions and actions of public authorities and officials. Administrative courts are designed to protect the rights of the individual, and this is their main function, which is associated with the implementation of the principle of protection of human rights in court. In general, the principles of administrative justice are legal actions due to the socio-economic and political principles of the state and society, directly covered by legal norms or follow from their content and reflect the basic requirements for fair consideration and resolution of administrative cases.

The issue of protection of the rights of individuals in administrative proceedings has not yet received the necessary comprehensive, thorough elaboration in domestic legal science, especially given the recent changes in the judiciary, the powers of higher courts to consider and resolve administrative cases. It is practically important to form a doctrinal theoretical basis for further reform, taking into account European principles, the domestic mechanism of judicial protection of the rights of individuals and legal entities in relations with public administration, the activities of administrative courts.

Aspects of procedural support at the level of the law of the rights of individuals to access to justice in administrative cases, issues of formation and development of the institution of administrative lawsuits, its concepts, elements and types, other means of ensuring the right to judicial protection are insufficiently theoretically developed by Ukrainian legal scholars. including at the stages of making, reviewing court decisions, as well as their implementation. This study is aimed at solving these and many other problems, which determines the relevance of its topic, the importance of both scientific and practical points of view. The European administrative procedure has been subject to study for the following domestic researchers: Iryna V. Boiko et al ${ }^{1}$ and Roman V. Shapoval et al. ${ }^{2}$ Many

\footnotetext{
${ }^{1}$ Boiko, Iryna V., Oleksandr T. Zyma, Yuliia V. Mekh, Olha M. Soloviova, and Valentyna A. Somina. "Administrative Procedure: European Standards and Conclusions for Ukraine." J. Advanced Res. L. \& Econ. 10 no. 7 (2019): 1968-75, https://doi.org/10.14505/jarle.v10.7(45).03

2 Shapoval, R. Volodymyrovych, Olga Ivanivna Demenko, and Khrystyna Volodymyrivna Solntseva. "The experience of the European Union in the field of administrative and legal support for asset-grabbing prevention." J. Advanced Res. L. \& Econ. 8 no. 3 (2017): 994-1008, https://doi.org/10.14505/jarle.v8. $\underline{3(25) .37}$
} 
scientific works, including such scholars as C. J. Hoofnagle, B. Sloot, and F. Z. Borgesius ${ }^{3}$, S. Greer, J. Gerards, and R. Slowe ${ }^{4}$, K. Gutman ${ }^{5}$, C. Bruzelius ${ }^{6}$ are devoted to the issues of the principle of protection of human rights and freedoms in the administrative proceedings of the European Union. The purpose of the relevant research is the formation of a uniform judicial enforcement in the field of public relations, the establishment of the rule of law and the provision of fair justice.

\section{Method}

The methodological basis of this study is a set of general scientific (dialectical, analysis and synthesis, etc.), as well as special legal (historical, comparative law, consideration and interpretation of legal norms, formal-logical, judicial statistics, etc.) methods of scientific knowledge. The dialectical method clarifies the place and role of administrative proceedings in the system of guarantees of the rights of individuals in relations with the authorities, in establishing the rule of law, legality and the principle of separation of state power. Methods of analysis and synthesis made it possible to explore existing aspects in the legal regulation of administrative court proceedings.

The application of the comparative legal method determines the place and features of the European mechanism of administrative proceedings in the field of protection of individual rights and freedoms in relations with the public authorities. Formal-legal and the method of consideration and interpretation of legal norms were used to determine the basic legal concepts of the studied issues. The method of deduction determines the legal and institutional mechanism of EU legislation in the field of human rights protection in administrative proceedings. The logical-semantic method contributed to the generalization, systematization and deepening of knowledge about the subject of research. The method of systematic analysis was used to clarify the principles and features that contribute to the implementation of effective protection of human rights in the administrative process. The application of the hermeneutic method during the research made it possible to properly interpret the regulations and scientific texts.

A number of articles related to the research topic were also analysed such as "The European Union as a human rights organization? Human rights and the core of the European Union"7, "Objectives and principles of administrative proceedings: Doctrinal

\footnotetext{
${ }^{3}$ Hoofnagle, Chris Jay, Bart van der Sloot, and Frederik Zuiderveen Borgesius. "The European Union general data protection regulation: What it is and what it means." Information and Communications Technology Law 28, no. 1 (2019): 65-98. https://doi.org/10.1080/13600834.2019.1573501

4 S. Greer, J. Gerards, and R. Slowe, "Human Rights in the Council of Europe and the European Union: Achievements, Trends and Challenges," Cambridge University Press 1, (2018): 89-95, https://doi.org/10.1017/9781139179041

${ }^{5}$ K. Gutman, "The Essence of the Fundamental Right to an Effective Remedy and to a Fair Trial in the Case-Law of the Court of Justice of the European Union: The Best Is Yet to Come?", German Law Journal 20, no. 6 (2019): 884-903.

6 C. Bruzelius, "Freedom of Movement, Social Rights and Residence-Based Conditionality in the European Union," Journal of European Social Policy 29, no. 1 (2019): 70-83.

${ }^{7}$ A.V. Bogdandy, "The European Union as a Human Rights Organization? Human Rights and the Core of the European Union," Common Market Law Review 37, no. 6 (2000): 1307-38.
} 
ideas and legislative" is and what it means" ${ }^{\prime}$, "Human rights in the Council of Europe and the European Union: Achievements, trends and challenges"10, "The essence of the fundamental right to an effective remedy and to a fair trial in the case-law of the Court of Justice of the European Union: The best is yet to come?"11, "Mutual trust before the Court of Justice of the European Union"12, "Development cooperation and human rights: Turbulent times for EU policy,"13 "Freedom of movement, social rights and residence-based conditionality in the European Union"14, "The rule of law in the European Union: the internal dimension"15, "Protection of the rights and interests of individuals in the public sphere in the judicial system of the European Union"16.

\section{Results}

\subsection{The concept and the standards of the European legal space}

Standards of judicial administrative process can be considered as an integral part of international human rights standards, as they are designed to ensure the appropriate level and effectiveness of judicial protection of human rights and freedoms in relations with public authorities and local governments. Administrative justice is an important guarantee of the legitimacy of the implementation of state and local authorities, their officials of the established powers; provides an opportunity to determine the quality of performance of duties established for officials; allows to implement the norms establishing the responsibility of state bodies and officials for non-performance or improper performance of their duties; contributes to the restoration of violated rights, freedoms and legitimate interests of individuals and legal entities. Therefore, the standards of administrative process can be defined as a system of legal norms, principles and legal customs that establish a mandatory (minimum) level of guarantee of individual rights in the administrative process and ways to exercise such rights.

In order to understand the concept of European standards for the implementation of the principle of effective protection of individual rights and freedoms in the administrative proceedings of the European Union (EU), in our opinion, it is necessary to take into account the concept of European legal space. Legal research proposes to define the European legal space as a legal system in its infancy, which consists of legal norms,

\footnotetext{
8 B.V. Makogon et al., "Objectives and Principles of Administrative Proceedings: Doctrinal Ideas and Legislative," Wordings of the Eastern European Countries 10, (2017): 221-30.

9 Hoofnagle, Sloot, and Borgesius, "The European Union General Data Protection," 68.

10 Greer, Gerards, and Slowe, "Human Rights," 89-93.

11 Gutman, "The Essence of the Fundamental Right", 899.

12 S. Prechal, "Mutual Trust Before the Court of Justice of the European Union European Papers," $A$ Journal on Law and Integration 1, (2017): 75-92.

13 K. Arts, "Development Cooperation and Human Rights: Turbulent Times for EU Policy," New perspectives on European Union Development Cooperation, no. 1 (2019): 7-27, https://doi.org/10.4324/ 9780429037047-2

14 Bruzelius, "Freedom of Movement," 75.

${ }^{15} \mathrm{~T}$. Konstadinides, The Rule of Law in the European Union: The Internal Dimension (London: Bloomsbury Publishing, 2017), 52.

16 Konstanty, "Protection of the Rights," 102-4.
} 
principles and standards developed within the framework of regional international organizations (Council of Europe, OSCE, EU). The Council of Europe is the most important component of the European legal space in the light of the protection of human rights (both in terms of the number of Member States and the list of rights guaranteed). It is the acts of the Council of Europe that contain detailed guarantees of the rights of the individual in legal proceedings, certain standards of such proceedings, to which this article is devoted. ${ }^{17}$

However, the term "European standards of administrative procedure" in the context of the proposed topic for more detailed study can be considered not only at the Council of Europe level (meaning such standards of the Convention of 1950 and the practice of their application by the European Court of Human Rights. in terms of interpretation of the Convention, ensuring uniform application of its norms by all member states and significantly affects the formation of common European standards), but also at the level of legal systems of individual European states, as the experience of the latter is interesting in terms of influencing the evolution of European standards. practices of their implementation in national legislation, national case law and legal doctrine. ${ }^{18}$

The rule of law is important in the implementation of the principle of effective protection of individual rights and freedoms in the administrative proceedings of the European Union. The implementation of the principle of the rule of law is impossible without the possibility of a person's access to an independent, impartial court, the proceedings in which meet the requirements of a fair trial. This is especially important in relations in the field of administrative law: decisions or actions that result from the exercise of power always have a direct impact on the rights and freedoms protected by the Convention for the Protection of Human Rights and Fundamental Freedoms. Recognizing the special nature of administrative acts, the member States of the Council of Europe must ensure that judicial authorities and the procedures for monitoring such acts comply with the requirements of the Convention and ensure their effectiveness. ${ }^{19}$

Leaving to the Member States the right to determine the limits and procedure for monitoring administrative acts, the Council of Europe seeks to develop certain common standards for the administrative process in order to ensure the protection of human rights in relations with the administrative authorities. The general standards of judicial procedure enshrined in the Convention are specified in the resolutions and recommendations of the Committee of Ministers of the Council of Europe on the improvement of the legislation of the member states in the field of judicial administrative procedure. On October 7-8, 2002, the Council of Europe organized the First Conference of Presidents of the Supreme Administrative Courts of Europe entitled "Possibility and

\footnotetext{
17 "European Standards of Administrative Process," Department of Justice, 2020, https://minjust.gov.ua/m/str_6738

18 "Convention for the Protection of Human Rights and Fundamental Freedoms," Council of Europe, 1950, https://www.eods.eu/library/CoE_European\%20Convention\%20for\%20the\%20Protection \%20of\%20Human\%20Rights\%20and\%20Fundamental\%20Freedoms_1950_EN.pdfx

19 Bogdandy, "The European Union," 1335.
} 
scope of judicial review of administrative decisions" 20 . The result of the Conference was the adoption of conclusions by its participants, in which they expressed support for the activities of the Project Group on Administrative Law. The latter was instructed by the Committee of Ministers of the Council of Europe, at the suggestion of the European Committee on Cooperation in the Field of Law, to develop a generally accepted instrument for judicial review of acts of administrative power.

It was emphasized at the conference (and later reflected in the documents of the Project Group on Administrative Law) that at the level of the Convention for the Protection of Human Rights and Fundamental Freedoms ${ }^{21}$ the general standards of judicial administrative procedure are enshrined in Article 13 and paragraph 1 of Article 6 (from a literal interpretation of the provisions of the Convention) did not provide for the extension of Article 6 to administrative proceedings, its application to judicial administrative proceedings is justified. According to Article $6 \S 1$ of the Convention "22, "in the determination of his civil rights and obligations or of any criminal charge against him, everyone is entitled to a fair and public hearing within a reasonable time by an independent and impartial tribunal. established by law ". The right to a fair trial is considered one of the most important rights guaranteed by the Convention. These include the right of access to a court, equality of arms, publicity of the trial and the announcement of a court decision or sentence, the enforcement of a judgment that has entered into force, and more. Thus, according to the text of the Convention, the exercise of the rights enshrined in Article $6 \S 1$ is guaranteed to a person only when a court determines his civil rights and obligations or when a criminal charge is brought against him. Thus, the application of Article 6 to a particular type of proceedings depends on whether the subject-matter of the proceedings, within the meaning of Article 6, belongs to "civil rights and obligations" or to "criminal charges".

With the development of the case-law of the Court, autonomous and evolutionary ways applied for interpreting the provisions of the Convention caused more and more disputes between a person and a state (even if such under domestic law belonged to public law). However, the recognition of disputes between natural and legal persons, on the one hand, and public authorities, on the other, as falling within the scope of Article $6 \S 1$ of the Convention, determines only the possibility of applying to the European Court of Justice after exhaustion of all domestic remedies. human rights. However, the basic principles of the judicial process, enshrined in Article $6 \S 1$, must be taken into account by national law and judicial practice (with the specific features of administrative proceedings), as they protect the rights of the individual in judicial proceedings and affect their effectiveness ${ }^{23}$.

The same conclusion was reached by the participants of the First Conference of Heads of Supreme Administrative Courts in Europe. The conclusions of the Conference stated that,

20 "Draft Recommendation of the Committee of Ministers to Member States on Judicial Review of Administrative Acts," The Committee of Ministers, 2004, https://rm.coe.int/CoERMPublicCommonSear chServices/DisplayDCTMContent?documentld=09000016805dba26

${ }^{21}$ Council of Europe, "Convention for the Protection of Human Rights and Fundamental Freedoms."

${ }^{22}$ Council of Europe, "Convention for the Protection of Human Rights and Fundamental Freedoms."

23 Makogon et al., "Objectives and Principles," 224. 
despite organizational differences in different states, the administrative process must meet the general standards enshrined in the legal systems of the Member States or the procedural guarantees explicitly enshrined in the Convention for the Protection of Human Rights and Fundamental Freedoms, in particular Articles 6 and 13. Under Article 13 of the Convention ${ }^{24}$, everyone whose rights and freedoms set forth in the Convention are violated shall have an effective remedy before a national authority notwithstanding that the violation has been committed by officials ${ }^{25}$. Therefore, the body referred to in this article is not necessarily a court, but it is important that it be able to provide an effective remedy. In cases where these functions of protection of the infringed right are exercised by the courts, the stricter requirements of Article $6 \S 1$ of the Convention, which absorbs Article 13, apply. However, such absorption does not occur in all cases. In some cases, Article 13 provides additional safeguards arising from the requirement of the effectiveness of the remedy: the possibility of suspending the contested decision or action of an administrative body if it may lead to irreparable damage, and imposing an obligation on the relevant body to compensate the damage cases) caused by a violation of the rights set out in the Convention. ${ }^{26}$

An analysis of Article $6 \S 1$ of the Convention and individual judgments of the European Court of Human Rights shows that the system of the right to a fair trial consists of such elements as: the right to a fair trial, the right to an open trial (including public proclamation); compliance with the criterion of "reasonable" time, independence and impartiality of the court established by law. However, the system of these elements cannot be considered complete without taking into account such important factors as the possibility of access to court for each person the effectiveness of judicial control over acts and actions (or inaction) of the administration. In a society based on the rule of law, one of the fundamental rights is the right to a court. In the case of "civil" cases, this means that everyone has the opportunity to sue for his civil rights or obligations ${ }^{27}$; in "criminal" cases, this means that no sanction can be applied other than by a court or under the control of a court. ${ }^{28}$

\subsection{Protection of individual rights and freedoms in the context of EU administrative law}

The manifestation of this right is the possibility for each person to go to court. With regard to administrative cases, this right is that anyone who considers that interference by an administrative authority in the exercise of his civil law is unlawful must be able to lodge an application with a court which meets the requirements of Article 6 of the Convention ${ }^{29}$. Accordingly, anyone who considers that a sanction imposed on him by an administrative body is illegal should be able to challenge the imposition of that sanction

\footnotetext{
${ }^{24}$ Council of Europe, "Convention for the Protection of Human Rights and Fundamental Freedoms."

25 The Committee of Ministers. "Draft Recommendation."

${ }^{26}$ Konstadinides, The Rule of Law, 55.

27 "Application no. 4451/70. Case of Golder v. United Kingdom," The European Court of Human Rights, 1975, https://www.bailii.org/eu/cases/ECHR/1975/1.html

28 "Application no. 6903/75. Deweer v. Belgium," The European Court of Human Rights, 1980, https://hudoc.echr.coe.int/fre\#\{\%22itemid\%22:[\%22001-57469\%22]\}

29 "Application no. 7151/75. Case of Sporrong and Lönnroth v. Sweden," The European Court of Human Rights, 1982.
} 
in court. Thus, Article 6 guarantees, in particular, the right to judicial review of administrative acts (including acts or omissions) ${ }^{30}$. The right of access to a court must be effective. This requirement in complex cases includes a system of legal aid for applicants who are unable to pay for the services of a lawyer. In this respect, the case of Airey v. Ireland ${ }^{31}$ should be noted, in which the European Court emphasized that in civil proceedings legal aid is not absolutely mandatory, as in criminal proceedings. However, the provision of legal aid is necessary in cases where the person himself cannot represent his interests or in cases where national law recognizes legal representation as mandatory. The Preliminary Draft Recommendation on the Judicial Review of Administrative Acts emphasizes, in addition to legal aid, the acceptability of the cost of going to court for the applicant and the sufficient time limits for filing an application ${ }^{32}$.

The requirement of efficiency also implies clarity of legislative provisions and transparency of the judicial control system. If the procedural rules are written in a way that creates some uncertainty (for example, how to determine the jurisdiction of the court, how to calculate the time limit for filing a complaint against an administrative act), persons whose applications were rejected on the grounds of violation of procedural rules are considered real, effective access to justice. For example, the judgment of the ECtHR in the case of Geouffre de la Pradelle v. France ${ }^{33}$. Finally, where enforcement of the impugned act has already begun, the effectiveness of the right of access should provide for the applicant's ability to demand termination or prevention of its immediate enforcement, and in the event of rejection of such a request, to conduct the trial with due diligence ${ }^{34}$.

To implement European standards of justice, one should primarily consider such international documents as the regulations of some Recommendations of the Council of Europe. Recommendation № R (81) 7 of the Committee of Ministers of the Council of Europe to member states on measures to facilitate access to justice ${ }^{35}$ identified the need to ensure that the public is properly informed and simplified forms of procedural documents, including court decisions. Achieving proper public information should be done by posting information about the court staff, its competence, reception times, contact details of the subject of power, through all available means of communication ( $T \mathrm{~V}$, radio, Internet, and also with the help of the print media and the placement of appropriate information stands in the premises of the judiciary) ${ }^{36}$. Leading role in the formation of EU administrative law, primarily from the standpoint of defining the main principles of public administration procedures and respect for the rights of individuals

30 Council of Europe, "Convention for the Protection of Human Rights and Fundamental Freedoms."

31 "Application no. 6289/73. Case of Airey v. Ireland," The European Court of Human Rights, 1979, https://hudoc.echr.coe.int/app/conversion/pdf?library=ECHR\&id=001-

73486\&filename=AIREY\%20V.\%20IRELAND.pdf

32 The European Court of Human Rights, "Application no. 6289/73. Case of Airey v. Ireland."

33 "Application no. 12964/87. Case of De Geouffre de la Pradelle v. France," The European Court of Human Rights, 1979, https://hudoc.echr.coe.int/app/conversion/pdf/?library=ECHR\&id=002-9920\& filename=002-9920.pdf\&TID=ihgdqbxnfi

34 "Application no. 34619/97. Case of Janosevic v. Sweden," The European Court of Human Rights, 2002.

35 "Recommendations No. R (81) 7 of the Committee of Ministers to Member States on Measures Facilitating Access to Justice," Council of Europe, 1981, https://rm.coe.int/168050e7e4

36 Hoofnagle, Sloot, and Borgesius, "The European Union General Data Protection," 68. 
(rule of law and direct effect of EU law, legal certainty, procedural justice, effective public administration, reasonableness and rationality of administrative decisions, responsibility states and EU institutions for illegal administrative actions, etc.) belongs to the Court of Justice of the European Union, which has the power to interpret primary EU legislation (treaties and protocols to them) and check for compliance with current EU laws (regulations, directives) and decisions (individual acts) EU institutions and, under certain conditions, Member States, in the context of improving the national system and practice of administrative justice. ${ }^{37}$

The principle of efficiency provides effective protection in administrative proceedings. Effective protection of rights somehow exists in all countries as an abstract guarantee or as a constitutional principle. The general functions of legal protection are: protection of the rights and legitimate interests of citizens (and organizations) against the arbitrariness of state bodies; ensuring access of individuals to effective means of protection of violated rights $^{38}$. Various instruments of legal protection can be used to protect a person's subjective rights; for example, in some countries the constitutional right of citizens to challenge government actions is a valuable tool for protecting and enforcing individual rights, in others the protection of rights rests with the prosecutor. In this context, protection is legal in nature, meaning that it is exercised not only by institutions but also by other means, such as through democratic accountability, moral commitment or other informal rules ${ }^{39}$. Judicial protection is a classic form of legal protection, but the concept of effective protection has a deeper meaning, as it is provided not only by judicial instruments, but also by general principles, substantive and procedural rights and institutional guarantees (e.g. protection of rights by the ombudsman). While legal protection has long been a well-established concept in national administrative justice systems, the requirement of "efficiency" has not always existed in legislation. In general, administrative justice provides some protection of private interests, even if they are not specified as specific legal law. ${ }^{40}$

Individuals may protect their rights and legitimate interests arising from EU law from violations of public law in the exercise of their powers by the EU institutions, their officials, or in the event of their inaction, including that which has resulted in damage to them, only in the manner of first of all appealing to the Court of General Jurisdiction, which at the same time largely acts as a body of administrative justice at the EU level. The Court of Justice (CJEU) is a court for privileged applicants (Member States, relevant EU bodies). Thus in part four of Art. 263 of the Treaty on the Functioning of the European Union (hereinafter - TFEU) ${ }^{41}$ establishes a rule that allows any natural or legal person to initiate proceedings in the General Court of the European Union (hereinafter - GCEU) not only against any decision of EU bodies addressed to that person or which concerns him directly and personally (individual act), but also against a regulatory act, if it applies directly to it. In other words, the TFEU Treaty enshrines a formula for individual judicial

37 Bruzelius, "Freedom of Movement," 75.

38 Boiko et al., "Administrative Procedure" 1974.

39 Konstanty, "Protection of the Rights," 102-4.

${ }^{40}$ Arts, "Development Cooperation," 10-17.

41 "Treaty on the Functioning of the European Union," Council of Europe, 2012, https://eurlex.europa.eu/legal-content/EN/TXT/?uri=celex\%3A12012E\%2FTXT 
protection, which allows individuals, in contrast to German administrative law, to challenge certain EU regulations (directives, etc.) provided that they apply to these persons and directly. restrict or violate their rights and legitimate interests guaranteed by acts with higher legal force (EU treaties, the Charter of Fundamental Rights or certain regulations).

This construction of locus standi (right to be a plaintiff in court) provides for the admission of individuals (subject to the requirement of address of the contested act) to the process of ensuring formal legality in the field of rule-making and law enforcement activities of EU institutions and indicates that the TFEU Treaty provides "interest", and not a "subjective" system of judicial protection in the public sphere. This brings it closer to the French model of administrative justice. And this state of affairs is quite logical given that the EU courts are territorially located in Luxembourg and the language of the proceedings is French. In Art. 41 of the EU Charter of Fundamental Rights ${ }^{42}$ defines the right of everyone within the EU to good (effective) governance, which is a guiding principle of modern European administrative law. In particular, it has been established that everyone has the right to have their case considered and decided impartially, fairly and within a reasonable time by EU institutions and bodies. This right includes, inter alia, guarantees of opportunities for each person: to be heard before the individual measures affecting him or her are implemented; access to information about oneself in compliance with legitimate interests, confidentiality, professional and trade secrets; the obligation of administrative bodies to motivate their decisions regarding the person; to make good any damage caused by EU institutions or officials in the exercise of their powers, in accordance with the general principles of the laws of the Member States; to contact the EU institutions and receive a reply from them in one of the official languages of the Treaties ${ }^{43}$.

In addition, in Art. 47 the EU Charter of Fundamental Rights ${ }^{44}$ enshrined, by analogy with Articles 6 and 13 of the Convention for the Protection of Human Rights and Fundamental Freedoms (hereinafter - ECHR) ${ }^{45}$, the right of everyone to an effective remedy and to a fair trial. In particular, it is provided that everyone whose rights and freedoms guaranteed by Union law have been violated has the right to: effective remedies before a court; for a fair and public hearing within a reasonable time by an independent and impartial tribunal previously established by law; protect yourself by any permitted means; to obtain legal assistance when he does not have sufficient funds. These provisions of the Charter, as well as the fundamental rights guaranteed by the ECHR, which are general principles of EU law (part three of Article 6 TEU), set out the principles for individuals to seek protection of their rights and legitimate interests under EU law ${ }^{46}$.

The EU Charter of Fundamental Rights is a newer document than the $1950 \mathrm{ECHR}$. In this regard, in addition to the fundamental human and civil rights and freedoms guaranteed

42 "Charter of Fundamental Rights of the European Union," Council of Europe, 2000, https://www.europarl.europa.eu/charter/pdf/text_en.pdf

${ }^{43}$ Council of Europe, "Charter of Fundamental Rights of the European Union."

${ }^{44}$ Council of Europe, "Charter of Fundamental Rights of the European Union."

${ }^{45}$ Council of Europe, "Convention for the Protection of Human Rights and Fundamental Freedoms."

${ }^{46}$ Greer, Gerards, and Slowe, "Human Rights," 89-93. 
by the Convention system, which belong mainly to civil and political groups, the Charter also enshrined "new" generations of human rights, recognized in later scientific discussions and theoretical developments, namely: solidarity (rights of workers, to social protection and assistance, to health care); information (for access to public information and personal data, protection of personal data); ecological (for environmental protection), for good (effective) management; consumer protection; cultural, religious and linguistic diversity; rights of disabled people and children, etc. This allows us to consider this document as a more modern, new and systematic tool for regulating the fundamental rights and freedoms of man and citizen, a reference point for the development of national constitutional and other legal regulation. The adoption of the Charter was intended to bring the EU closer to its citizens.

In recent years, in the practice of GCEU, cases on claims of individuals for judicial protection under Art. 41 of the Charter "Right to Good Administration" 47 in the adoption of individual decisions by the EU institutions and, under certain conditions, regulations, in particular to ensure that everyone is heard before the issuance of a legal act directly affecting them, the right of access to public information, the duty of the administration to motivate its decisions. Thus, in the judgment in French Republic v. The People's Mojahedin Organization of Iran ${ }^{48}$, the GCEU defended the fundamental right defined in paragraph "a" of part two of Art. 41 of the Charter ${ }^{49}$ on the right of everyone to be heard before certain measures concerning him or her, including in the negative, are taken by the EU institutions or bodies. The court found that before taking restrictive measures (in this case, the organization's assets were frozen), the relevant authority should notify the addressee in advance so that he could correct the errors (offenses) by obtaining the necessary information.

\section{Discussion}

All Member States of the European Union must ensure effective judicial protection of their rights. Such protection is, first of all, the availability of legal remedies for the parties to administrative proceedings, for persons whose rights have been violated by an act of an administrative body. With regard to national courts, the principle of effective protection is aimed at the availability of remedies against alleged violations of subjective, mainly property, and massive passive nature. It does not provide for effective actions of the subject due to violation of legal rights or interests, only a guarantee to provide all possible means for further effective action.

In France in particular, although the law does not explicitly enshrine the principle of effective redress, it follows from certain general principles. French law does not guarantee procedural rights. The reason for this is that in the French approach, the law is seen as an objective order aimed at the goals of effective governance. However, the

\footnotetext{
${ }^{47}$ Council of Europe, "Charter of Fundamental Rights of the European Union."

48 "Application no. C-27/09 P. Case of French Republic v. People's Mojahedin Organization of Iran," The European Court of Human Rights, 2011, https://eur-lex.europa.eu/legal-content/EN/TXT/?uri= CELEX\%3A62009CJ0027

${ }^{49}$ Council of Europe, "Charter of Fundamental Rights of the European Union."
} 
principles of an effective remedy, effective protection of rights and a fair trial recognize and cover the following requirements: equal rights of access to administration and administrative documents; the right to substantiate court decisions and the obligation of administrative bodies to substantiate their decisions; the principle of equality of arms in adversarial administrative proceedings, the right to be heard, the right to remedies and access to courts, where independent and impartial judges decide cases within a reasonable time (such rights are in fact meaningful components of effective protection $)^{50}$.

French administrative law is, in essence, based on case law, which creates certain problems for the accessibility of the law. The current French model of administrative justice is inherent not only in France but also in Germany, Belgium, Italy, the Netherlands, Luxembourg, Greece and other developed countries. In Spain, the principles of equality and effective protection of rights in administrative proceedings are principles of constitutional significance that guarantee the right to effective legal protection. In Germany, the activities of administrative courts are enshrined in the Constitution of the Federal Republic and constitute an effective model for the exercise of a citizen's right to judicial protection against violation of his rights by public authorities.

In Hungary, the history of the development of the principle of effective legal protection dates back to the second half of the nineteenth century, during the dual monarchy with Austria. Although the principle of effective protection still does not have an independent legislative basis, it follows from the principle of a fair trial enshrined at the Constitutional level. According to the provisions of the Constitution, any (natural or legal) person whose rights or legitimate interests have been directly violated by an administrative act may appeal it in court. A peculiarity is the existence of three types of constitutional complaints in Hungarian legislation. The "axio popularis" system means the legal possibility for anyone to apply to the Constitutional Court, claiming that a law, legal position or legal regulation is generally contrary to constitutional provisions, and to demand the annulment of a decision, action or act. The purpose of a constitutional complaint is also to protect a person from infringement, in particular during a trial or administrative proceeding. Among the rights to protection is also a mechanism to appeal to the ombudsman. The Commissioner for Fundamental Rights and Freedoms (Parliamentary Ombudsman) may initiate a procedure for "ex-growth facto" review of the law in the Constitutional Court. The Commissioner for Human Rights has broad powers to investigate the work of administrative bodies, and may initiate various procedures to compensate for damage or restore the rights or legitimate interests of citizens. At the same time, the prosecutor is obliged to control the legality of final or regulatory decisions made by administrative bodies if the appeal against the decision has not been considered by the court ${ }^{51}$.

In our opinion, the principle of effective protection of rights is so deeply rooted in EU law that some scholars are certain that it has a quasi-constitutional status. All relevant parts of EU law have their origins in the general constitutional traditions of the Member States, as is clearly recognized in the founding documents of European integration and in the

\footnotetext{
50 Gutman, "The Essence of the Fundamental Right", 899.

51 Prechal, "Mutual Trust," 82.
} 
case law of the European courts. In general, the principle of effective protection provides for the possibility of a person whose rights or interests have been violated by public administration bodies to use the legal remedies available and guaranteed by the state for effective protection to restore their rights; to appeal against administrative acts in court, to present their own evidence in the course of the proceedings, and, in general, to promote the restoration of justice by their effective actions.

In each state, the principle of effective protection of rights and freedoms is implemented in different legal ways and in different areas, depending on the model of organization of administrative justice. For the successful legal reform and European integration of Ukraine, it is important to take into account the practice of European states in the protection of individual rights in relations with public authorities to amend existing legislation. It is worth noting that the positive experience and high standards of European countries are gradually being introduced into the rule-making process in the Code of Administrative Procedure. However, the consolidation of the basic principles of administrative courts at the constitutional level (for example, France, Germany, Hungary and other countries) will contribute to the implementation of the principles established by the provisions of international instruments. At the same time, administrative courts must be provided with separation from general courts and judicial independence when considering public law disputes.

\section{Conclusion}

In the modern world, administrative justice is the only universal institution for the protection of legally enshrined rights and legitimate interests of citizens, which embodies a combination of two independent mechanisms, namely the executive and judicial branches of government. In addition, this institution is recognized as universal both within the national legal system and on a global scale. Taking into account the achievements of European states in the field of administrative process, legal standards developed at the European level, the study of the case law of the European Court of Human Rights is necessary to develop and improve the theoretical and regulatory framework of administrative courts in Ukraine. The system of proper protection of human rights and freedoms is one of the important conditions of the European administrative space. The effectiveness of the national system for ensuring the protection of human rights and freedoms depends on the success of the process of implementation and convergence of European Union legislation, taking into account not only its content but also its form.

One of the main tasks of administrative law is to determine the legal boundaries, grounds and procedures of bodies and officials of public administration, as well as means of guaranteeing the rights of individuals that may be violated in making administrative decisions, these subjects have certain legally significant actions. or inaction. Therefore, an integral part of administrative law, its mandatory component in many countries, including Ukraine, is the institution of administrative justice (judiciary), which in the context of judicial reform, which continues in our country, requires qualitative improvement. Proper regulation of the right to appeal against regulations and individual 
administrative acts is an integral part of the rule of law and a guarantee of human rights and freedoms, the balance of private and public interests as priorities of the public administration system. Standards of administrative process can be defined as a system of legal norms, principles and legal customs that establish a mandatory (minimum) level of guarantee of individual rights in the administrative process and ways to exercise such rights. Compliance with the rule of law is a priority international and European principle of the administration of justice. The principle of the rule of law is understood as a set of the following elements: the rule of law in the sense of achieving transparency, accountability and democratic law and order in the development, adoption and implementation of national laws; legal certainty; taking measures to overcome the manifestations of bureaucratic arbitrariness; ensuring access to justice, including the establishment of a mechanism for appealing against administrative acts; equality before the law and the elimination of possible forms of discrimination.

\section{References}

Arts, Karen. "Development Cooperation and Human Rights: Turbulent Times for EU Policy." New perspectives on European Union Development Cooperation, no. 1 (2019): 7-27. https://doi.org/10.4324/9780429037047-2

Bogdandy, A.V. "The European Union as a Human Rights Organization? Human Rights and the Core of the European Union." Common Market Law Review 37, no. 6 (2000): 1307-38.

Boiko, I.V., O.T. Zyma, Y.V. Mekh, O.M. Soloviova, and V.A. Somina. "Administrative Procedure: European Standards and Conclusions for Ukraine." Journal of Advanced Research in Law and Economics 10, no. 7 (2019): 1968-75. https://doi.org/10.14505/jarle.v10.7(45).03

Bruzelius, C. "Freedom of Movement, Social Rights and Residence-Based Conditionality in the European Union." Journal of European Social Policy 29, no. 1 (2019): 70-83.

Council of Europe. "Convention for the Protection of Human Rights and Fundamental Freedoms." 1950. https://www.eods.eu/library/CoE European\%20Convention\% 20for\%20the\%20Protection\%20of\%20Human\%20Rights\%20and\%20Fundamental \%20Freedoms 1950 EN.pdfx

Council of Europe. "Recommendations No. R (81) 7 of the Committee of Ministers to Member States on Measures Facilitating Access to Justice." 1981. https://rm.coe.int/168050e7e4

Council of Europe. "Treaty on the Functioning of the European Union." 2012. https://eurlex.europa.eu/legal-content/EN/TXT/?uri=celex\%3A12012E\%2FTXT

Council of Europe. "Charter of Fundamental Rights of the European Union." 2000. https://www.europarl.europa.eu/charter/pdf/text en.pdf

Department of Justice. "European Standards of Administrative Process." 2020. https://minjust.gov.ua/m/str 6738 
Greer, S., J. Gerards, and R. Slowe. "Human Rights in the Council of Europe and the European Union: Achievements, Trends and Challenges." Cambridge University Press 1, (2018): 89-95. https://doi.org/10.1017/9781139179041

Gutman, K. "The Essence of the Fundamental Right to an Effective Remedy and to a Fair Trial in the Case-Law of the Court of Justice of the European Union: The Best Is Yet to Come?" German Law Journal 20, no. 6 (2019): 884-903.

Hoofnagle, C.J., B. Sloot, and F.Z. Borgesius. "The European Union General Data Protection Regulation: What It Is and What It Means." Information and Communications Technology Law 28, no. 1 (2019): 65-98. https://doi.org/10.1080/13600834.2019.1573501

Konstadinides, T. The Rule of Law in the European Union: The Internal Dimension. London: Bloomsbury Publishing, 2017.

Konstanty, O.V. "Protection of the Rights and Interests of Individuals in the Public Sphere in the Judicial System of the European Union." Bulletin of the High Council of Justice 1, no. 13 (2013): 102-16.

Makogon, B.V., M.I. Nikulin, V.N. Samsonov, M.A. Sorokoletova, and J. Tovstukha. "Objectives and Principles of Administrative Proceedings: Doctrinal Ideas and Legislative." Wordings of the Eastern European Countries 10, (2017): 221-30.

Prechal, Sacha. "Mutual trust before the Court of Justice of the European Union." European Papers-A Journal on Law and Integration 2017, no. 1 (2017): 75-92.

Shapoval, R.V., O.I. Demenko, and K.V. Solntseva. "The Experience of the European Union in the Field of Administrative and Legal Support for Asset-Grabbing Prevention." Journal of Advanced Research in Law and Economics 8, no. 3 (2017): 994-1008. https://doi.org/10.14505/jarle.v8.3(25).37

The Committee of Ministers. "Draft Recommendation of the Committee of Ministers to Member States on Judicial Review of Administrative Acts." 2004. https://rm.coe.int/CoERMPublicCommonSearchServices/DisplayDCTMContent?do cumentld=09000016805dba26

The European Court of Human Rights. "Application no. 12964/87. Case of De Geouffre de la Pradelle v. France." 1979. https://hudoc.echr.coe.int/app/conversion/pdf/? library=ECHR\&id=002-9920\&filename=002-9920.pdf\&TID=ihgdqbxnfi

The European Court of Human Rights. "Application no. 4451/70. Case of Golder v. United Kingdom." 1975. https://www.bailii.org/eu/cases/ECHR/1975/1.html

The European Court of Human Rights. "Application no. 6289/73. Case of Airey v. Ireland." 1979. https://hudoc.echr.coe.int/app/conversion/pdf?library=ECHR\&id=00173486\&filename=AIREY\%20V.\%20IRELAND.pdf

The European Court of Human Rights. "Application no. 6903/75. Deweer v. Belgium." 1980. https://hudoc.echr.coe.int/fre\#\{\%22itemid\%22:[\%22001-57469\%22] \} 
The European Court of Human Rights. "Application no. 7151/75. Case of Sporrong and Lönnroth v. Sweden." 1982. https://blog.uclm.es/cienciaspenales/files/2016/ 10/21sporrong-proteccion-de-la-propiedad.-titularidad-y-alcance.-privacion-legalde-la-propiedad.-in.pdf

The European Court of Human Rights. "Application no. C-27/09 P. Case of French Republic v. People's Mojahedin Organization of Iran." 2011. https://eur-lex.europa.eu/legalcontent/EN/TXT/?uri=CELEX\%3A62009CJ0027

Conflict of Interest Statement: The author(s) declares that the research was conducted in the absence of any commercial or financial relationship that could be construed as a potential conflict of interest.

Copyright: (C) HALREV. This is an open access article distributed under the terms of the Creative Commons Attribution 4.0 International License (CC-BY 4.0), which permits unrestricted use, distribution, and reproduction in any medium, provided the original author and source are credited.

Hasanuddin Law Review (Hasanuddin Law Rev. - HALREV) is an open access and peer-reviewed journal published by Faculty of Law, Hasanuddin University, Indonesia. 